\title{
Consequences of Customer Value Co-creation in Restaurants
}

\section{Abuelkassem A.A. Mohammad}

Hotel Management Department, Faculty of Tourism and Hotels, Minia University

\section{ARTICLE INFO}

Keywords:

Co-creation, perceived personalization, brand love, customer satiation, switching behavior.

\section{(JAAUTH) \\ Vol. 20, No. 1, (2021), \\ PP. 111-128.}

\begin{abstract}
Many hospitality enterprises nowadays seek to engage their customers in the process of value creation. This study investigated the concept of co-creation of the dining experience and its outcomes. It aimed to: (1) examine the direct effects of co-creation of dining experience on perceived personalization, brand love, customer satiation, and switching behavior, (2) test the direct effects of both perceived personalization and brand love on customer satiation and switching behavior, and (3) assess the mediation effects of both perceived personalization and brand love on the linkage between co-creation and customer satiation as well as between co-creation and switching behavior. A quantitative approach was adopted in this study using a questionnaire survey for primary data collection. The sample included a total of 615 domestic customers of restaurants in Egypt. Structural equation modeling using Smart-PLS 3.2 was performed to test the hypothesized conceptual model. The results revealed that the impact of dining experience co-creation on perceived personalization and brand love was positive, while it was negative on customer satiation and nonsignificant on switching behavior. The findings also confirmed the mediation effects of both perceived personalization and brand love. This study addresses a gap in the hospitality literature and provides some valuable managerial implications.
\end{abstract}

\section{Introduction}

Increased demand for personalized services and products has led many tourism and hospitality enterprises to involve their guests in the process of creating a service experience- a phenomenon known as value co-creation (Lei et al., 2020). Also, the strong rivalry and proliferation of hospitality brands forced many hospitality firms to adopt attachment-oriented strategies, such as brand love, to retain customers (Shin \& Back, 2020). Maintaining current customers and mitigating switching behaviors is critical for reducing marketing costs and business success (Park \& Jang, 2014). However, Customer propensity to switch service providers is inevitable, even satisfied customers tend to occasionally try different products and services to fulfill their desires for variety and novelty or to indulge their curiosity and vanity (Lin \& Mattila, 2006). Thus, hospitality managers always aspire to figure out proper 
strategies or techniques to mitigate customer switching intentions and behaviors (Line et al., 2016). The current study investigates the co-creation of the dining experience as an antecedent for mitigating switching behavior. Also, the study examines both brand love and perceived personalization as mediating variables that can be used to lessen switching behavior among restaurant customers.

The significant role of value co-creation in the tourism and hospitality domain has been emphasized by several studies (e.g. Mathis et al., 2016; Prebensen \& Xie, 2017; Assiouras et al., 2019). Nevertheless, A limited number of studies investigated the concept of co-creation in restaurant settings and linked it to critical marketing outcomes such as brand love, personalization, satiation, and switching behavior. Specifically, Mak et al. (2012) argued that food services represent an important sector of the hospitality industry and encouraged further investigation of the factor that influence food consumption among customers. Similarly, Kamboj and Gupta (2018) argued that studies on customer co-creation in the hospitality field remain scarce, particularly when it comes to investigating this concept from a customer perspective. Park and Jang, (2014) endorsed further investigations of various antecedents for satiation and switching behaviors. In a similar vein, (Line et al., 2016) advocated studying potential intervening variables that can help practitioners develop a prevention strategy to stem undesirable outcomes caused by customer satiation.

Therefore, the current study aims to address this gap and contribute to the hospitality literature by suggesting and examining a conceptual model that includes interrelationships among co-creation, personalization, brand love, satiation, and switching behavior. Specifically, this study examines: (1) the direct effects of cocreation of dining experience on perceived personalization, brand love, customer satiation, and switching behavior; (2) the direct effects of both perceived personalization and brand love on customer satiation and switching behavior; (3) the mediation effects of both perceived personalization and brand love on the linkage between co-creation and customer satiation as well as between co-creation and switching behavior. Doing so enhances our understanding of the potential consequences of co-creation and informs practitioners to undertake adequate practices to alleviate customer satiation and mitigate switching behaviors.

\section{Theoretical background}

\subsection{Co-creation of the dining experience}

In the service-dominant logic (S-DL) paradigm, customers are considered as cocreator of value because they ultimately determine the value of service experience (Vargo \& Lusch, 2008). Value co-creation refers to customers' involvement in designing and customizing service experiences to better suit their personal needs and preferences (Chiu et al., 2017; Lei et al., 2020). That is, customers actively participate in creating a personalized service experience through sharing information, suggestions, and preferences as well as through cooperating with employees and other customers to get optimal value of services (Chiu et al., 2017). It is a consumerenterprise interaction whereby customers are permitted to suggest changes in the features of a value proposition and the enterprise in turn gets to adjust the value accordingly (Morosan \& DeFranco, 2019). The literature provides several models for 
implementing value co-creation in the service sector (Prahalad \& Ramaswamy, 2004; O'Hern \& Rindfleisch, 2010; Echeverri \& Skalén, 2011; Grönroos, 2012) that all emphasized that co-creation is the joint interaction between customers and service providers (Zhang et al., 2018).

In this context, many service enterprises adopted different ways to engage their consumers in the service creation process and allow them to participate in developing customized services (Kamboj \& Gupta, 2018). Similarly, value co-creation in hospitality enterprises involves engaging guests in the creation and delivery of a service through sharing resources that enable them to co-design, select and modify various attributes of the service experience to better suit their desires ( Kamboj \& Gupta, 2018; Assiouras et al., 2019; Lei et al., 2020). For instance, a hotel guest can customize his or her accommodation experience before or upon arrival by requesting specific features such as room type, view, amenities, and meals. Also, the hotel can use a customer preference database to suggest certain services or improvements that guests might be interested in (Chathoth et al., 2016). In the same vein, restaurants allow their customers to co-create various elements of the dining experience such as selecting tables, customizing backgrounds, and viewing projected images of food items before ordering (Chathoth et al., 2016).

\subsection{Perceived personalization}

Tourism and hospitality enterprises are considered as "personalized boutique" that serves the demands of various guests through providing customized services (Chathoth et al., 2016). Personalization of service refers to the process of utilizing customers' personal information about needs and preferences to design the service offerings in a way that matches those specific needs and preferences (Piccoli et al., 2017). This process involves changing some elements of the service offering such as product/features, delivery, or service encounter according to customer profile (Piccoli et al., 2017). That is, personalization occurs when the value is based on individual characteristics as it reflects the extent to which a customer perceives a service/product to fulfill his or her personal needs and wants (Assiouras et al., 2019; Lei et al., 2020).

\subsection{Brand love}

Brand love is defined as the emotional attachment developed by satisfied customers toward a particular brand name (Carroll \& Ahuvia, 2006; Shin \& Back, 2020). Shin and Back (2020) explained that brand love is a construct that encompasses three dimensions: (1) intimacy-feelings of closeness, (2) passion and includes arousal and involvement, and (3) commitment which refers to maintain a relationship for a long term. Brand love has recently captured the attention of hospitality scholars due to its critical influence on several marketing outcomes such as positive word of mouth, repurchase intentions, and switching resistance ( Carroll \& Ahuvia, 2006; Batra et al., 2012; Wang et al., 2019; Shin \& Back, 2020).

\subsection{Satiation}

Satiation refers to the decreased overall enjoyment of repeated consumption (Redden \& Galak, 2013; Galak et al., 2009). In other words, it is the phenomenon of feeling less enjoyment as a result of frequent exposure to the same stimulus ( Sevilla \& 
Redden, 2014; Line et al., 2016). Satiation can be explained from both physiological and psychological aspects. From a physiological or appetite perspective, satiation refers to the feeling of fullness and suppression of further food intake ( Redden \& Galak, 2013; Park \& Jang, 2014). Meanwhile, psychologically speaking, satiation refers to negative emotional outcomes such as boredom or dullness caused by repeated exposure to the same stimulus or consumption experience (Berlyne, 1970; Park \& Jang, 2014). That is, restaurant customers are likely to get bored at some point because of frequent dining at the same place results in marginally less arousal and excitement, which is explained by the law of diminishing marginal utility ( Park \& Jang, 2014; Line et al., 2016; Line \& Hanks, 2019). Some scholars ( Park \& Jang, 2014; Line et al., 2016) noticed that although satiation has been the focus of many studies in various service settings, it was only recently investigated in the dining and restaurant industry.

\subsection{Switching behavior}

Switching intention refers to customer propensity or tendency to change the current service provider (Yin, 1997). It is the likelihood of exchanging transactions from a customer's current enterprise to another one (Bolton et al., 2004; Park \& Jang, 2014). Meanwhile, switching behavior refers to the consumer's actual act of replacing one service provider with another (Wu et al., 2018). Various reasons can provoke customers' switching behavior such as price inconvenience, low service quality, ethical concerns, and trust (Jung \& Yoon, 2012; Park \& Jang, 2014).

\section{Hypotheses and conceptual model}

\subsection{Co-creation, personalization, brand love, satiation and switching behavior}

Co-creation in essence is a process of designing and producing personalized services and products ( Smaliukiene et al., 2014; Piligrimienè et al., 2015). Therefore. it is reasonable to assume that co-creation of the dining experience has a positive impact on the perceived personalization of provided services. In fact, it was argued that the more efforts customer invests in the co-creation process, the higher level of personalized experience he or she will get (Oyner \& Korelina, 2016). Previous research showed that customer co-creation can positively influence the perception of service personalization. For example, Lei et al. (2020) reported a significant positive impact of experience co-creation via mobile applications on the perceived personalization of tourism and hospitality service. Accordingly, the present study assumes the following hypothesis:

Hypothesis 1: co-creation of the dining experience positively impacts perceived personalization

Involving customers in the process of creating service offerings based on their personal preferences (i.e. co-creation) makes them feel like business partners, not just regular consumers which results in many favorable marketing outcomes such as customer satisfaction (Kamboj \& Gupta, 2018) and tourist citizenship behavior (Assiouras et al., 2019). For example, Kamboj \& Gupta, (2018) reported a positive impact of value co-creation on guest satisfaction in Indian hotel settings. Assiouras et al. (2019) also empirically reported a positive association between engagement in co- 
creation and tourist citizenship behaviors. Therefore, this study assumes that the cocreation of dining experience enables customers to develop an emotional attachment with the firm which enhances brand love and alleviates customer satiation and switching behavior. This study postulates the following hypotheses:

Hypothesis 2: co-creation of the dining experience positively impacts brand love

Hypothesis 3: co-creation of the dining experience negatively impacts customer satiation

Hypothesis 4: co-creation of the dining experience negatively impacts switching behavior

\subsection{Perceived personalization, brand love, satiation and switching behavior}

Ball et al. (2006) explained that designing the service offerings to fit customer individual requirements results in long-term loyalty because personalized services are more satisfying and hard to replace. Hence, it can be assumed that perceived personalization reduces customer switching behavior, which is the opposite concept of customer loyalty (Bolton et al., 2004; Park \& Jang, 2014). Personalization also can alleviate the sense of satiation through providing tailored services that fulfill customer-specific preferences resulting in a satisfactory transaction (Ball et al., 2006). Likewise, emotional attachment with a brand image represents a critical barrier for customer switching behavior, and thereby it helps enterprises to retain current customers and minimize leaving or switching behavior (Wang et al., 2019). In this context, the study of Carroll and Ahuvia (2006) reported a significant positive impact of brand love on customer loyalty. Thus, the study postulates the following hypotheses:

Hypothesis 5: perceived personalization has a negative effect on customer satiation

Hypothesis 6: perceived personalization has a negative effect on switching behavior

Hypothesis 7: brand love has a negative effect on customer satiation

Hypothesis 8: brand love has a negative effect on switching behavior

\subsection{Satiation and switching behavior}

The decline of perceived benefit or hedonic value of services below a certain degree derives customers to seek substitutes that stimulate their arousal and excitement ( Park \& Jang, 2014; Line et al., 2016; Line \& Hanks, 2019). Some precedent research reported that customer satiation is a major antecedent for switching intentions which in turn leads to actual switching behavior. For instance, the study of Park \& Jang (2014) examined the impact of satiation on switching intentions among sample restaurant customers in the USA. The results showed that satiation has a significant positive impact on customers' intentions to switch. The current study examines the impact of satiation on actual switching behavior and posits the following hypothesis:

Hypothesis 9: customer satiation has a positive influence on switching behavior. 


\subsection{Mediation effects of perceived personalization and brand love}

Customer involvement in creating a dining experience positively contributes to the perceived personalization of food services (Lei et al., 2020). According to Bolton et al. and (2004) Ball et al. (2006), the perception of personalized services result in customer loyalty and repeat business. Thus, this study assumes that perceived personalization can mediate the linkages between co-creation of dining experience and both customer satiation and switching behavior as follows:

Hypothesis 10a: perceived personalization mediates the linkage between co-creation and customer satiation

Hypothesis 10b: perceived personalization mediates the linkage between co-creation and switching behavior

On that note, Assiouras et al. (2019) also reported that customer engagement in value co-creation enhances customer citizenship, a concept that is similar to brand love. Carroll and Ahuvia (2006) explained that brand love can alleviate customer sense of satiation while Wang et al. (2019) reported that brand love enhances customer loyalty. Accordingly, the current study predicts a mediation role of brand love in the association between dining experience co-creation and both satiation and switching behavior and postulates the following assumptions:

Hypothesis 11a: brand love mediates the linkage between co-creation and customer satiation

Hypothesis 11b: brand love mediates the linkage between co-creation and customer switching behavior

In light of the above discussions, this study suggests a conceptual model that illustrates the hypothesized linkages among the investigated constructs (see Figure 1).

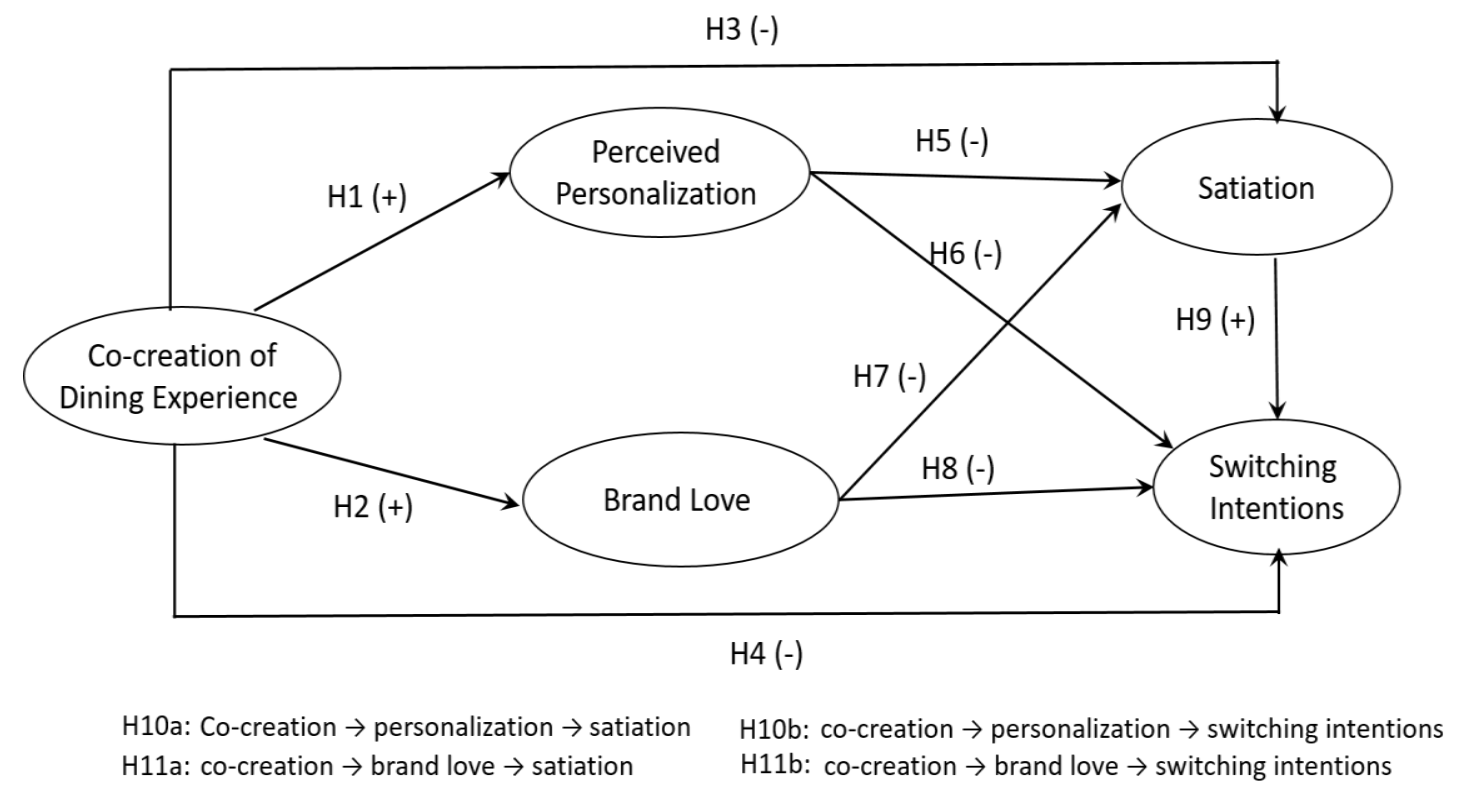

Fig.1. conceptual model of the study 


\section{Methodology}

\subsection{Measurement}

The current study adopted a quantitative approach and used a questionnaire survey as a tool for collecting primary data. The questionnaire form included seven main sections. Section one was an introduction and presented the research aims, explained the volunteer nature of participation, and confirmed the anonymity of participants and the confidentiality of their personal data. Section two addressed characteristics of the respondents including gender, age group, marital status, and weekly dining frequency. The other five sections presented the scales for measuring variables of the study where section three measured co-creation of the dining experience, section four captured perceived personalization, section five addressed brand love, section six measured customer satiation, and lastly section seven addressed switching behavior.

All items used for measuring constructs of this study were adapted from previous research (Appendix A). Specifically, co-creation of the dining experience was measured by five items that were adapted from the study of Mathis et al. (2016), while perceived personalization was measured by four items taken from the study of Lei et al. (2020). A three-dimensional scale with a total of 12 items was adapted from Shin and Back (2020) to measure brand love. These items were parceled into their dimensions using the mean technique suggested by Little et al. (2002). To capture customer satiation, a two-item scale was taken from the study of Park and Jang (2014). Lastly, switching behavior was measured using three items adapted from the study of Hussain and Rizwan (2014). Some items were slightly edited to fit the study. All scales were anchored by a different headline statement and were measured on a five-point Likert scale $(1=$ strongly disagree and $5=$ strongly agree $)$.

\subsection{Participants and procedures}

The population of this study includes domestic patrons of restaurants in Egypt. Due to accessibility and time issues, a convenience sampling technique was adopted in this study to recruit the participants in the survey. Both paper-based and web-based questionnaire forms were utilized to reach study participants. A total of 900 questionnaire forms were distributed among study candidates, including 300 paperbased forms and 600 web-based surveys using Google Forms service. Out of the disseminated forms, 649 forms were completed and returned with an approximate response rate of $72 \%$. Returned survey forms were checked and 34 forms were excluded for incompleteness or insincerity concerns leaving 615 valid forms for analysis. According to hair et al. (2016), this sample size is sufficient for examining the proposed model using Smart-PLS software as it significantly exceeds the suggested minimum sample size (ten times the number of arrowheads directed to a latent construct). Also, using different sample size calculator websites (calculator.net and surveysystem.com) indicated that a minimum sample size of 385 is acceptable for an infinite population at a confidence level of $95 \%$ and an interval of $\pm 5 \%$.

\subsection{Data analysis techniques}

A Partial Least Square Structural Equation Modelling (PLS-SEM) using Smart-pls 3.0 was utilized to examine the postulated hypotheses of this study. Following the analysis procedures of PLS-SEM suggested by Hair et al. (2016), both the 
measurement model and the structural model were assessed. The measurement model was examined through testing common method bias and establishing reliability and construct validity by looking at several statistics including Cronbach alpha, composite reliability, average variance extracted, heterotrait-monotrait. Meanwhile, the structural model was examined by evaluating beta, $t$-statistics, and $p$-value..

\section{Results}

\subsection{Profile of the participants}

The sample of this study represented various demographic segments from the target population (Table 1). Specifically, both genders were included in the sample with a large share $(63 \%)$ of the male participants compared to the percentage of females $(37 \%)$. As for marital status, the majority of the participants $(48 \%)$ were married followed by the "others" category at $35.5 \%$ including engaged and widowers, and only $16.5 \%$ of the participants were single. Youth, or people between 20 and 39 years, were the dominant age group at $47 \%$ followed by the younger age group (less than 20 years) at $27 \%$. Grownups (between 40 and 59 years) came at the third rank with $19 \%$ and lastly, senior citizens came at the last rank at $7 \%$. When it comes to the weekly frequency of dining, a large percentage $(38.5 \%)$ of the participants have dined out three times or less per week followed by people with a higher frequency of dining out (between 4 and 6 times) at 34.6\%. A slight portion of the participants $(20.5 \%)$ had higher repeat patronage and dined out between 7 to 9 times a week, meantime only $6.4 \%$ of the respondents dined out more than 9 times a week.

\section{Table 1}

Profile of participants

\begin{tabular}{|cll|}
\hline Gender & Freq. & $\%$ \\
\hline Male & 387 & $63 \%$ \\
\hline Female & 228 & $37 \%$ \\
\hline Total & 615 & 100 \\
\hline Marital status & Freq. & $\%$ \\
\hline Single & 102 & $16.5 \%$ \\
\hline Married & 295 & $48 \%$ \\
\hline Others (engaged, widowed, etc.) & 218 & $35.5 \%$ \\
\hline Total & 615 & 100 \\
\hline Age group & Freq. & $\%$ \\
\hline Less than 20 years & 166 & $27 \%$ \\
\hline Between 20 to less than 40 & 289 & $47 \%$ \\
\hline Between 40 to less than 60 & 117 & $19 \%$ \\
\hline 60 years or more & 43 & $7 \%$ \\
\hline Total & 615 & 100 \\
\hline Dining frequency (weekly) & Freq. & $\%$ \\
\hline Three times or less & 237 & $38.5 \%$ \\
\hline Between 4 to 6 times & 213 & $34.6 \%$ \\
\hline Between 7 to 9 times & 126 & $20.5 \%$ \\
\hline More than 9 times & 39 & $6.4 \%$ \\
\hline Total & 615 & 100 \\
\hline
\end{tabular}




\subsection{Measurement model}

\subsubsection{Common method bias (CMB)}

A self-rated survey can threaten the integrity of data by allowing some shared variation among the indicators (Kock, 2015). Therefore, this stud undertook some proactive measures to mitigate this issue. First, the research assured the anonymity of the participants and the confidentiality of their personal information to encourage honest and accurate responses. Also, scale items were taken from previous studies to guarantee the use of valid and reliable measures. Also, a full collinearity test was performed to ensure that $\mathrm{CMB}$ did not contaminate the data. The results showed that CMB was not a threat for the collected data as the values of the outer Variance Inflation Factor $(1.464 \leq \mathrm{VIF} \leq 2.582)$ did not exceed the threshold of 3.3 which confirmed that data was CMB free (Kock, 2015).

\subsubsection{Reliability and construct validity}

The present study used several statistics to assert the reliability and validity of its measures (see tables 2 and 3). First, Cronbach's alpha $(0.753 \leq \alpha \leq 0.878)$, Rho $(0.758 \leq \rho \mathrm{A} \leq 0.880)$, and composite reliability $(0.858 \leq \mathrm{CR} \leq 0.943)$ were higher than 0.70 which confirmed the internal consistency reliability of all measures. Next, convergent validity was examined by looking at the significance of outer loading $(0.704 \leq \lambda \leq 0.947 ; 16.201 \leq \mathrm{t} \leq 87.397)$ and average variance extracted values $(0.619 \leq$ AVE $\leq 0.891$ ) which asserted the convergent validity of the study measures. Finally, discriminant validity was also ensured as the correspondent square root of AVE was greater than correlation coefficients $(-0.431 \leq \phi \leq 0.791 ; 0.791 \leq \sqrt{ }$ AVE $\leq 0.944)$ (Fornell \& Larcker, 1981) and no heterotrait-monotrait ratio greater than the threshold of HTMT0.90 (Henseler et al., 2015).

\section{Table 2}

Reliability and convergent validity of measures $(\mathrm{n}=615)$

\begin{tabular}{|c|c|c|c|c|c|c|}
\hline Constructs and Indicators & loadings & t-statistics & Alpha & Rho A & $\mathrm{CR}$ & AVE \\
\hline Co-creation of the dining experience & & & 0.845 & 0.849 & 0.890 & 0.619 \\
\hline CDE01 & 0.788 & $30.984 *$ & & & & \\
\hline CDE02 & 0.799 & $32.321 *$ & & & & \\
\hline CDE03 & 0.805 & $33.858^{*}$ & & & & \\
\hline CDE04 & 0.830 & $42.588^{*}$ & & & & \\
\hline CDE05 & 0.704 & $19.252^{*}$ & & & & \\
\hline $\begin{array}{l}\text { Perceived personalization }\left(\mathrm{R}^{2}=0.625 ;\right. \\
\left.\mathrm{Q}^{2}=0.412\right)\end{array}$ & & & 0.753 & 0.758 & 0.858 & 0.669 \\
\hline PER01 & 0.820 & $34.029 *$ & & & & \\
\hline PER02 & 0.839 & $46.414 *$ & & & & \\
\hline PER03 & 0.794 & $26.410 *$ & & & & \\
\hline PER04 & 0.732 & $13.521^{*}$ & & & & \\
\hline Brand love $\left(\mathrm{R}^{2}=0.635 ; \mathrm{Q}^{2}=0.421\right)$ & & & 0.760 & 0.761 & 0.862 & 0.675 \\
\hline INTM & 0.833 & $42.622 *$ & & & & \\
\hline PASN & 0.822 & $32.021 *$ & & & & \\
\hline CMTM & 0.811 & $34.245^{*}$ & & & & \\
\hline Satiation $\left(\mathrm{R}^{2}=0.245 ; \mathrm{Q}^{2}=0.211\right)$ & & & 0.878 & 0.880 & 0.943 & 0.891 \\
\hline SAT01 & 0.941 & $87.397 *$ & & & & \\
\hline
\end{tabular}




\begin{tabular}{|c|c|c|c|c|c|c|}
\hline SAT02 & 0.947 & $16.201 *$ & & & & \\
\hline $\begin{array}{l}\text { Switching behavior } \quad\left(\mathrm{R}^{2}=0.323 \text {; }\right. \\
\left.\mathrm{Q}^{2}=0.248\right)\end{array}$ & & & 0.870 & 0.872 & 0.920 & 0.793 \\
\hline SWT01 & 0.876 & $45.475^{*}$ & & & & \\
\hline SWT02 & 0.910 & $75.655^{*}$ & & & & \\
\hline SWC03 & 0.886 & $61.821 *$ & & & & \\
\hline
\end{tabular}

Table 3

Discriminant validity of constructs

\begin{tabular}{|l|c|c|c|c|c|}
\hline & $\mathrm{A}$ & $\mathrm{B}$ & $\mathrm{C}$ & $\mathrm{D}$ & $\mathrm{E}$ \\
\hline $\begin{array}{l}\text { A. Co-creation of the dining } \\
\text { experience }\end{array}$ & $\mathbf{0 . 7 9 1}$ & 0.689 & 0.792 & 0.558 & 0.541 \\
\hline B. Perceived personalization & 0.786 & $\mathbf{0 . 8 1 8}$ & 0.441 & 0.549 & 0.532 \\
\hline C. Brand love & 0.790 & 0.791 & $\mathbf{0 . 8 2 2}$ & 0.525 & 0.565 \\
\hline D. Satiation & -0.482 & -0.449 & -0.429 & $\mathbf{0 . 9 4 4}$ & 0.559 \\
\hline E. Switching behavior & -0.467 & -0.431 & -0.459 & 0.488 & $\mathbf{0 . 8 9 1}$ \\
\hline
\end{tabular}

The Square root of AVE is bolded, lower triangular are bivariate correlation coefficients, upper triangular is HTMT ratio of correlations.

\subsection{Structural model}

\subsubsection{Direct parameters estimate}

Before examining the postulated hypotheses, the study asserted the adequacy of the model fit by examining the values of the standardized root mean square residual $(\mathrm{SRMR}=0.064)$ and the normed fit index $(\mathrm{NFI}=0.903)$ which confirmed the model's goodness-of-fit (Henseler et al. 2014). The results (Table 4) showed that co-creation of the dining experience has positively and significantly influenced perceived personalization $(\beta 1=091 ; \mathrm{t} 1=28.855)$ and brand love $(\beta 2=0.797 ; \mathrm{t} 2=29.783)$. However, it had a significant negative impact on customer satiation $(\beta 3=-0.312$; $\mathrm{t} 3=3.044)$ and a nonsignificant negative effect on switching behavior $(\beta 4=-0.137$; $\mathrm{t} 4=0.109$ ). Hence, these results provide strong support for hypotheses 1,2 , and 3 while hypothesis 4 was not supported. The effect of perceived personalization on customer satiation was negative $(\beta 5=-0.158)$ and significant $(\mathrm{t} 5=1.962)$ while its impact on switching behavior was negative $(\beta 6=-0.027)$ but not significant ( $\mathrm{t} 6=$ $0.329)$. Thus, hypothesis 5 was accepted but hypothesis 6 was not. The findings also showed that brand love had a negative $(\beta 7=-0.056)$ but nonsignificant $(t 7=0.591)$ influence on customer satiation, yet it had a significant negative effect on switching behavior $(\beta 8=-0.187 ; \mathrm{t} 3=2.078)$. Such findings did not support hypothesis 7 but it supported hypothesis 8 . Lastly, customer satiation had a significant positive impact on switching behavior $(\beta 9=0.330 ; t 9=4.534)$ which provided proper support for hypothesis 9. 


\section{Table 4}

Coefficients and significances of direct paths

\begin{tabular}{|l|l|l|l|l|l|}
\hline H\# & Paths & $\beta$ & $t$-value & $F^{2}$ & Decision \\
\hline H1 & Co-creation $\rightarrow$ perceived personalization & 0.791 & $28.855^{* * *}$ & 1.669 & Supported \\
\hline H2 & Co-creation $\rightarrow$ brand love & 0.797 & $29.783^{* * *}$ & 1.737 & Supported \\
\hline H3 & Co-creation $\rightarrow$ satiation & -0.312 & $3.044^{* * *}$ & 0.038 & Supported \\
\hline H4 & Co-creation $\rightarrow$ switching behavior & -0.137 & 0.109 & 0.008 & Not Supported \\
\hline H5 & Perceived personalization $\rightarrow$ satiation & -0.158 & $1.962^{*}$ & 0.010 & Supported \\
\hline H6 & Perceived personalization $\rightarrow$ switching behavior & -0.027 & 0.329 & 0.010 & Not Supported \\
\hline H7 & Brand love $\rightarrow$ satiation & -0.056 & 0.591 & 0.001 & Not Supported \\
\hline H8 & Brand love $\rightarrow$ switching behavior & -0.187 & $2.078^{* *}$ & 0.015 & Supported \\
\hline H9 & Satiation $\rightarrow$ switching behavior & 0.330 & $4.534^{* * *}$ & 0.121 & Supported \\
\hline
\end{tabular}

$* \mathrm{p}<0.05 ; * * \mathrm{p}<0.005 ; * * * \mathrm{p}<0.001$

In the light of Cohen's (2013) guidelines for the F2 values, the results revealed that co-creation of dining experience had a large effect on both perceived personalization $(\mathrm{F} 2=1.669)$ and brand love $(\mathrm{F} 2=1.737)$, a medium effect on satiation $(\mathrm{F} 2=0.038)$, and no effect on switching behavior $(\mathrm{F} 2=0.008)$. The effect of perceived personalization was almost nonexistent on satiation and switching behavior $(\mathrm{F} 2=0.01$ each). Similarly, brand love had no effect on satiation $(\mathrm{F} 2=0.001)$ and a very small effect on switching behavior $(F 2=0.015)$ while satiation had a small effect on switching behavior $(\mathrm{F} 2=0.121)$.

\subsubsection{Mediated parameters estimate}

A mediation analysis was performed to examine the role of both perceived personalization and brand love on the association between co-creation and both satiation and switching behavior. The results (Table 5) showed that perceived personalization significantly mediated the linkage between co-creation and customer satiation (effect $=-0.125 ; \mathrm{t} 3=1.965$ ) while it has not mediated the linkage between co-creation and switching behavior (effect $=-0.022 ; \mathrm{t} 3=0.328$ ). In a similar vein, the mediation effect of brand love on the association between co-creation and satiation was not significant (effect $=-0.045 ; \mathrm{t} 3=0.587$ ) but it was significant on the linkage between co-creation and switching behavior (effect $=-0.149 ; \mathrm{t} 3=2.061$ ).

\section{Table 5}

Results of mediation effects

\begin{tabular}{|l|l|l|l|l|}
\hline H\# & Mediation effects & effect & $t$-value & Decision \\
\hline H10a & Co-creation $\rightarrow$ personalization $\rightarrow$ satiation & -0.125 & $1.965^{*}$ & Supported \\
\hline H10b & Co-creation $\rightarrow$ personalization $\rightarrow$ switching behavior & -0.022 & 0.328 & Not Supported \\
\hline H11a & Co-creation $\rightarrow$ brand love $\rightarrow$ satiation & -0.045 & 0.587 & Not Supported \\
\hline H11b & Co-creation $\rightarrow$ brand love $\rightarrow$ switching behavior & -0.149 & $2.061^{*}$ & Supported \\
\hline
\end{tabular}

$* \mathrm{p}<0.05 ; * * \mathrm{p}<0.005 ; * * * \mathrm{p}<0.001$

\section{Conclusion and implications}

This study contributes to the growing hospitality marketing literature through investigating the concept of co-creation of the dining experience as a predictor of some critical outcomes including perceived personalization, brand love, customer satiation, and switching behavior which addresses a gap acknowledged by several 
previous studies (Mak et al., 2012; Park \& Jang, 2014; Line et al., 2016; Kamboj \& Gupta, 2018).

Concerning its hypotheses, the current study revealed some interesting findings. The results confirmed that engaging customers in creating a dining experience is an advantageous process that leads to many favorable marketing outcomes such as the enhanced perception of service personalization and strong emotional attachment to the restaurant brand. Likewise. involving customers in customizing the dining service increases customer enjoyment of repeated dining experience which in turn mitigates customers' sense of satiation. These findings add to prior studies which reported that value co-creation in the service sector is associated with several desirable consequences such as customer satisfaction (Kamboj \& Gupta, 2018), customer citizenship behavior (Assiouras et al., 2019), and perceived personalization of services (Lei et al., 2020).

The study also revealed that perceived personalization of dining experience can alleviate customer sense of satiation as it lessened the boredom and stimulated enjoyment and arousal associated with food consumption experience. This conclusion is supported by Ball et al. (2006). However, the results indicated that perceived personalization did not diminish customer behaviors of switching restaurants which contradicts the results of previous studies (Bolton et al., 2004; Park \& Jang, 2014). Contrarily, brand love or emotional attachment with restaurant brand did not affect customer satiation, yet it has contributed to reducing customer switching behavior. The latter finding agrees with Wang et al. (2019) and Shin and Back (2020).

Consistently with its direct effects on customer satiation, perceived personalization had a significant mediation effect in the linkage between co-creation and customer satiation. That is, customer involvement in designing dining experience has improved his or her perception of service personalization which in its turn lightened customer satiation. Similarly, brand love acted as a significant mediator in the association between co-creation and switching behavior. In other words, allowing customers to co-develop their dining experience can encourage repeat customers and mitigate switching behavior through stimulating customer affective attachment with the restaurant brand. These findings represent a novel theoretical contribution of this study, given the limited number of studies that examined the mediating effects of perceived personalization and brand love in the indirect linkage between co-creation of dining experience and both customer satiation and switching behavior.

Some practical suggestions can be endorsed based on the empirical findings of this study. Restaurants managers are advised to involve customers in the process of developing and creating the service offerings to enhance and personalize the overall dining experience which leads to customer retention and repeat business through minimizing customer satiation and switching behaviors. This can be accomplished through empowering customers and enabling proper communication channels that allow them to share their suggestions and convey their dining presences and desires. In this context, information technology and social media provide adequate platforms for engaging customers in the process of creating a dining experience. 
Restaurant managers are encouraged to adopt a personalized service approach due to its critical role in averting customer satiation. To that end, it is recommended to gather and utilize customer information regarding food likes, dislikes, and desires to provide customized dining services that satisfy individual needs or preferences. Also, considering customer post-consumption comments or feedback is another salient technique to identify customer-specific needs to be fulfilled in the next visit. Another practical suggestion that worth recommending includes developing and exploiting customer emotional attachment with the restaurant brand as a customer retention strategy to prevent or minimize leaving intentions and switching behaviors.

Customer satiation is a key driver for switching behaviors, thereby restaurant managers ought to identify and assume convenient procedures to break this connection. In this respect, restaurant managers can undertake several practices such as providing new services or products or renovating and upgrading service offerings including food items, décor, music, staff uniform, service style, table layout, etc. Doing so will stimulate customer arousal and enjoyment and lessen the boredom caused by repeated exposure to the same dining elements.

\section{Limitations and future research}

The present study has some constraints as well as suggestions for future research. The questionnaire survey included only domestic customers of restaurants in Egypt and thereby their responses can be influenced by local economic and sociocultural characteristics. Thus, it is suggested that future studies investigated the viewpoint of international guests or both domestic and international to compare between these two segments and examine the possible effects of sociocultural factors on the investigated variables. Further research can also adopt a qualitative approach to produce more detailed data and insights regarding possible procedures to engage restaurant customers in the co-creation process and its effects on different consequences such as repeat patronage or expenditure. Moreover, future research can propose and examine potential moderators, such as customer surprise, to alleviate the association between co-creation and customer satiation and switching behaviors.

\section{References}

Assiouras, I., Skourtis, G., Giannopoulos, A., Buhalis, D., \& Koniordos, M. (2019). Value co-creation and customer citizenship behavior. Annals of Tourism Research, 78, 102742. https://doi.org/10.1016/j.annals.2019.102742

Ball, D., Coelho, P. S., \& Vilares, M. J. (2006). Service personalization and loyalty. Journal of Services Marketing, 20(6), 391-403. https://doi.org/10.1108/08876040610691284

Batra, R., Ahuvia, A., \& Bagozzi, R. P. (2012). Brand love. Journal of Marketing, 76(2), 1-16.

Berlyne, D. E. (1970). Novelty, complexity, and hedonic value. Perception \& Psychophysics, 8(5), 279-286. https://doi.org/10.3758/BF03212593

Bolton, R. N., Lemon, K. N., \& Verhoef, P. C. (2004). The Theoretical Underpinnings of Customer Asset Management: A Framework and Propositions 
for Future Research. Journal of the Academy of Marketing Science, 32(3), 271292. https://doi.org/10.1177/0092070304263341

Carroll, B. A., \& Ahuvia, A. C. (2006). Some antecedents and outcomes of brand love. Marketing Letters, 17(2), 79-89.

Chathoth, P. K., Ungson, G. R., Harrington, R. J., \& Chan, E. S. W. (2016). Cocreation and higher order customer engagement in hospitality and tourism services: A critical review. International Journal of Contemporary Hospitality Management, 28(2), 222-245. https://doi.org/10.1108/IJCHM-10-2014-0526

Chiu, W., Shin, S., \& Lee, H.-W. (2017). Value Co-Creation in Fitness Centers: The Role of Customer Citizenship Behavior on Perceived Value, Satisfaction, and Repurchase Intention. In Handbook of research on strategic alliances and value co-creation in the service industry (pp. 415-430). IGI Global.

Cohen, J. (2013). Statistical power analysis for the behavioral sciences. Academic press.

Echeverri, P., \& Skalén, P. (2011). Co-creation and co-destruction: A practice-theory based study of interactive value formation. Marketing Theory, 11(3), 351-373.

Fornell, C., \& Larcker, D. F. (1981). Evaluating structural equation models with unobservable variables and measurement error. Journal of Marketing Research, 18(1), 39-50.

Galak, J., Redden, J. P., \& Kruger, J. (2009). Variety Amnesia: Recalling Past Variety Can Accelerate Recovery from Satiation. Journal of Consumer Research, 36(4), 575-584. https://doi.org/10.1086/600066

Grönroos, C. (2012). Conceptualising value co-creation: A journey to the 1970s and back to the future. Journal of Marketing Management, 28(13-14), 1520-1534.

Hair, Ringle, C., \& Sarstedt, M. (2016). A primer on partial least squares structural equation modeling (PLS-SEM). Sage publications.

Henseler, J., Dijkstra, T. K., Sarstedt, M., Ringle, C. M., Diamantopoulos, A., Straub, D. W., ... Calantone, R. J. (2014). Common beliefs and reality about PLS: Comments on Rönkkö and Evermann (2013). Organizational Research Methods, 17(2), 182-209.

Henseler, J., Ringle, C. M., \& Sarstedt, M. (2015). A new criterion for assessing discriminant validity in variance-based structural equation modeling. Journal of the Academy of Marketing Science, 43(1), 115-135.

Hussain, K., \& Rizwan, M. (2014). Customer loyalty and switching behavior of customer for Pepsi in Pakistan. Journal of Public Administration and Governance, 4(2), 129-145.

Jung, H. S., \& Yoon, H. H. (2012). Why do satisfied customers switch? Focus on the restaurant patron variety-seeking orientation and purchase decision involvement. International Journal of Hospitality Management, 31(3), 875-884. https://doi.org/10.1016/j.ijhm.2011.10.006 
Kamboj, S., \& Gupta, S. (2018). Use of smart phone apps in co-creative hotel service innovation: An evidence from India. Current Issues in Tourism, 23(3), 323-344. https://doi.org/10.1080/13683500.2018.1513459

Kock, N. (2015). Common method bias in PLS-SEM: A full collinearity assessment approach. International Journal of E-Collaboration (Ijec), 11(4), 1-10.

Lei, S. I., Ye, S., Wang, D., \& Law, R. (2020). Engaging Customers in Value CoCreation Through Mobile Instant Messaging in the Tourism and Hospitality Industry. Journal of Hospitality \& Tourism Research, 44(2), 229-251. https://doi.org/10.1177/1096348019893066

Lin, I. Y.-H., \& Mattila, A. S. (2006). Understanding Restaurant Switching Behavior from a Cultural Perspective. Journal of Hospitality \& Tourism Research, 30(1), 3-15. https://doi.org/10.1177/1096348005284266

Line, N. D., \& Hanks, L. (2019). Boredom-Induced Switching Behavior in the Restaurant Industry: The Mediating Role of Attachment. Journal of Hospitality \& Tourism Research, 43(1), 101-119. https://doi.org/10.1177/1096348018762579

Line, N. D., Hanks, L., \& Kim, W. G. (2016). Hedonic adaptation and satiation: Understanding switching behavior in the restaurant industry. International Journal of Hospitality Management, 52, 143-153. https://doi.org/10.1016/j.ijhm.2015.10.005

Little, T. D., Cunningham, W. A., Shahar, G., \& Widaman, K. F. (2002). To parcel or not to parcel: Exploring the question, weighing the merits. Structural Equation Modeling, 9(2), 151-173.

Mak, A. H. N., Lumbers, M., Eves, A., \& Chang, R. C. Y. (2012). Factors influencing tourist food consumption. International Journal of Hospitality Management, 31(3), 928-936. https://doi.org/10.1016/j.ijhm.2011.10.012

Mathis, E. F., Kim, H. L., Uysal, M., Sirgy, J. M., \& Prebensen, N. K. (2016). The effect of co-creation experience on outcome variable. Annals of Tourism Research, 57, 62-75.

Morosan, C., \& DeFranco, A. (2019). Co-creation of value using hotel interactive technologies: Examining intentions and conversion. International Journal of Contemporary Hospitality Management, 31(3), 1183-1204. https://doi.org/10.1108/IJCHM-04-2018-0314

O'Hern, M. S., \& Rindfleisch, A. (2010). Customer co-creation: A typology and research agenda. Review of Marketing Research, 6(1), 84-106.

Oyner, O., \& Korelina, A. (2016). The influence of customer engagement in value cocreation on customer satisfaction: Searching for new forms of co-creation in the Russian hotel industry. Worldwide Hospitality and Tourism Themes, 8(3), 327345. https://doi.org/10.1108/WHATT-02-2016-0005

Park, J. Y., \& Jang, S. C. S. (2014). Why do customers switch? More satiated or less satisfied. International Journal of Hospitality Management, 37, 159-170. https://doi.org/10.1016/j.ijhm.2013.11.007 
Piccoli, G., Lui, T.-W., \& Grün, B. (2017). The impact of IT-enabled customer service systems on service personalization, customer service perceptions, and hotel performance. Tourism Management, 59, 349-362. https://doi.org/10.1016/j.tourman.2016.08.015

Piligrimienè, Ž., Dovalienè, A., \& Virvilaitè, R. (2015). Consumer Engagement in Value Co-Creation: What Kind of Value it creates for Company? Engineering Economics, 26(4), 452-460. https://doi.org/10.5755/j01.ee.26.4.12502

Prahalad, C. K., \& Ramaswamy, V. (2004). Co-creating unique value with customers. Strategy \& Leadership.

Prebensen, N. K., \& Xie, J. (2017). Efficacy of co-creation and mastering on perceived value and satisfaction in tourists' consumption. Tourism Management, $60,166-176$.

Redden, J. P., \& Galak, J. (2013). The subjective sense of feeling satiated. Journal of Experimental Psychology: General, 142(1), 209.

Sevilla, J., \& Redden, J. P. (2014). Limited Availability Reduces the Rate of Satiation. Journal of Marketing Research, 51(2), 205-217. https://doi.org/10.1509/jmr.12.0090

Shin, M., \& Back, K.-J. (2020). Effect of Cognitive Engagement on the Development of Brand Love in a Hotel Context. Journal of Hospitality \& Tourism Research, 44(2), 328-350. https://doi.org/10.1177/1096348019890055

Smaliukiene, R., Chi-Shiun, L., \& Sizovaite, I. (2014). CONSUMER VALUE COCREATION IN ONLINE BUSINESS: THE CASE OF GLOBAL TRAVEL SERVICES. Journal of Business Economics and Management, 16(2), 325-339. https://doi.org/10.3846/16111699.2014.985251

Vargo, S. L., \& Lusch, R. F. (2008). Service-dominant logic: Continuing the evolution. Journal of the Academy of Marketing Science, 36(1), 1-10. https://doi.org/10.1007/s11747-007-0069-6

Wang, Y.-C., Qu, H., \& Yang, J. (2019). The formation of sub-brand love and corporate brand love in hotel brand portfolios. International Journal of Hospitality Management, 77, 375-384.

Wu, H.-C., Wei, C.-F., Tseng, L.-Y., \& Cheng, C.-C. (2018). What drives green brand switching behavior? Marketing Intelligence \& Planning, 36(6), 694-708. https://doi.org/10.1108/MIP-10-2017-0224

Yin, L. T. W. (1997). An empirical study of customer switching behaviour in service industries [PhD Thesis]. Chinese University of Hong Kong.

Zhang, T. C., Jahromi, M. F., \& Kizildag, M. (2018). Value co-creation in a sharing economy: The end of price wars? International Journal of Hospitality Management, 71, 51-58. https://doi.org/10.1016/j.ijhm.2017.11.010 


\section{Appendix A}

\section{Measurement items}

Co-creation of the dining experience (Mathis et al., 2016)

1. (CDE01) Working with the staff allowed me to have greater social interaction, which I enjoyed.

2. (CDE02) I felt comfortable working with the staff member regarding my dining arrangements.

3. (CDE03) The digital communication environment allowed us to collaborate effectively

4. (CDE04) My overall dining experience was enhanced because I specified my personal needs and preferences.

5. (CDE05) I felt confident in my ability to collaborate with the staff member

Perceived personalization (Lei et al., 2020)

1. (PER01) My overall dining experience was more memorable

2. (PER02) My dining experience was tailored to me.

3. (PER03) The restaurant offered me products and services that satisfy my specific needs

4. (PER04) The restaurant personalized my experience based on the information that I shared.

Brand love (Shin \& Back, 2020)

Intimacy (INTM)

1. I feel emotionally close to my regular restaurant

2. I have a comfortable relationship with my regular restaurant

3. I feel like I really understand my regular restaurant

4. There is a certain intimacy between me and my regular restaurant

Passion (PASN)

1. I cannot imagine another restaurant making me as happy as my regular

2. I adore my regular restaurant

3. My regular restaurant makes me feel great delight

4. Just seeing my regular restaurant is exciting for me

Commitment (CMTM)

1. I am committed to maintaining a relationship with my regular restaurant

2. I plan to continue the relationship with my regular restaurant

3. I view my relationship with my regular restaurant as a good decision

4. I have confidence in the stability of my relationship with my regular restaurant Satiation (Park \& Jang, 2014)

1. (SAT01) The most recent dining experience was not as enjoyable as previous visits

2. (SAT01) The most recent dining experience was not as exciting as previous visits

Switching behavior (Hussain \& Rizwan, 2014)

1. (SWT01) I intend to switch this restaurant.

2. (SWT01) Next time I shall dine at another restaurant.

3. (SWT01) I would not continue to dine at this restaurant 


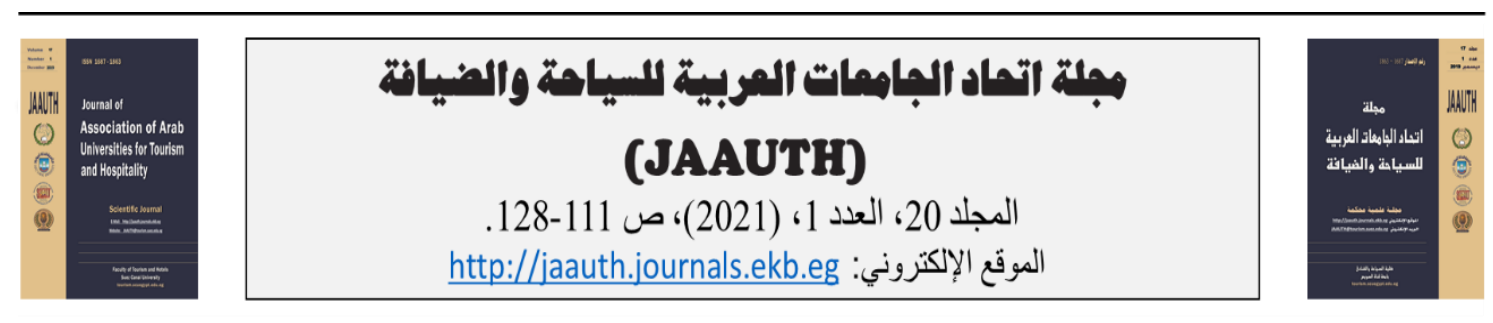

\section{تبعات مشاركة العملاء في إنشاء القيمة في المطاعم \\ مؤمن كامل أبو العز \\ أبو القاسم عبدالوهاب عبدالله محمد}

قسم إدارة الفنادق، كلية السياحة والفنادق، جامعة المنيا

تسعى العديد من مؤسسات الضيافة في الوقت الحاضر إلى إشراك عملائها في

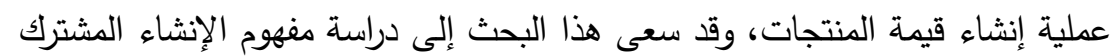

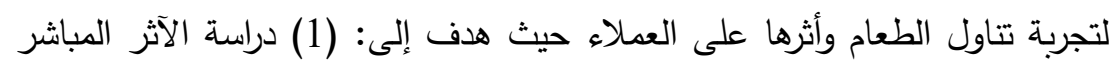
للمشاركة في إنثاء تجربة تتاول الطعام على إدراك تخصيص الخدمة، وحب العلامة الخها

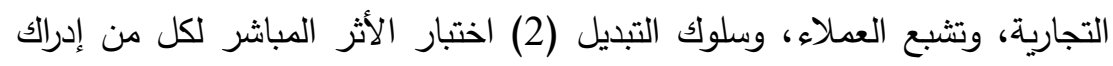
تخصيص الخدمة وحب العلامة التجارية على تثبع العملاء وسلوك التبديل، (3)

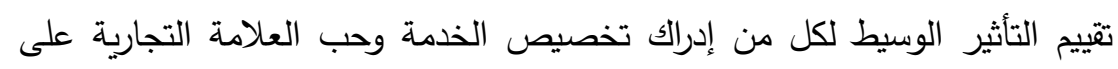

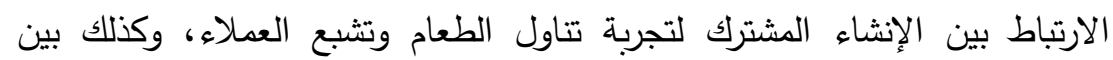
الإنثاء المشترك لتجربة تتاول الطعام وسلوك التبديل. تم استخدام المنهج الكمي في هذه الدراسة باستخدام الاستبيان لجمع البيانات الأولية. تم إستخدام أسلوب العينة الملائمة، وقد شملت عينة الدراسة عدد 615 من العملاء المحليين للمطاعم في

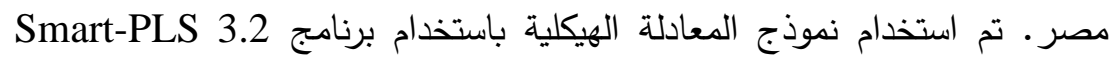

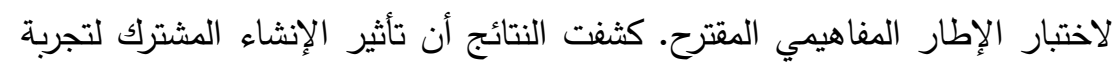
تناول الطعام على إدراك تخصيص الخدمة وحب العلامة التجارية كان إيجابيًا، في حين كان تأثيرًا سلبيًا على تثبع العملاء وغير دال إحصائيا علي سلوك التبديل.

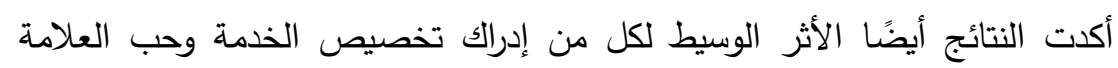
التجارية في العلاقه بين الإنثاء المشترك لتجربة تتاول الطعام وتثبع العملاء. عالجت الدراسة الحالية فجوة في أدبيات الضيافة وقدمت بعض التوصيات الإدارية. 